\title{
Comparative measurement of FeLV load in hemolymphatic tissues of cats with hematologic cytopenias
}

\author{
Mehdi Abdollahi-Pirbazari ${ }^{1}$, Shahram Jamshidi ${ }^{1}$, Seyed Mahdi Nassiri ${ }^{2^{*}}$ (D) and Mohamad Zamani-Ahmadmahmudi ${ }^{3}$
}

\begin{abstract}
Background: Feline leukemia virus (FeLV) is a serious viral infection in cats. FeLV is found in some tissues, such as spleen, lymph nodes and epithelial tissues. However, there is controversy about the organ in which the virus can be reliably detected in infected cats. The purpose of this study was to determine the level of viral infection in hemolymphatic tissues, including blood, bone marrow and spleen by reverse-transcriptase quantitative polymerase chain reaction (RT-qPCR).

Results: A total of 31 cats with clinical signs of FeLV infection associated with at least a single lineage hematologic cytopenia were included in this study. Peripheral blood, bone marrow and spleen samples were obtained from each cat. Complete blood counts, biochemical tests, and a rapid test to detect FeLV p27 antigen in blood samples of cats were performed. Of 31 cats, 9 had anemia alone, 4 had thrombocytopenia alone, 2 had neutropenia alone, 9 had bicytopenia of anemia and thrombocytopenia, 3 had bicytopenia of anemia and neutropenia, and 4 had pancytopenia. FeLV RNA was then detected by RT-qPCR in the whole blood, bone marrow and spleen. Viral RNA copy numbers were detected in all cats by RT-qPCR whereas 24 out of 31 cats were positive for the serum FeLV antigen. We detected a significantly greater number of viral RNA in the spleen compared with the whole blood and bone marrow.
\end{abstract}

Conclusion: Spleen is a site where FeLV is most frequently detected in cats with hematologic cytopenias.

Keywords: Cat, Cytopenia, Feline leukemia virus, RT-qPCR

\section{Background}

Feline leukemia virus (FeLV) is a retrovirus belonging to the family Retroviridae, subfamily Orthoretrovirinae, genus Gammaretrovirus, which is responsible for infection, tumor development and immunological dysfunction in domestic cats [1-4]. Viremic cats serve as sources of infection for other cats, which can be transmitted via saliva, nasal secretions, urine, feces, and milk [5]. The virus replicates in many epithelial tissues, including salivary glands, oropharynx, esophagus, stomach, intestine, trachea, nasopharynx, renal tubules, bladder, pancreas, alveolar ducts, and sebaceous glands $[6,7]$. The virus has two single-RNA strands which are converted to DNA (provirus) by the enzyme reverse

\footnotetext{
* Correspondence: nasirim@ut.ac.ir

${ }^{2}$ Department of Clinical Pathology, Faculty of Veterinary Medicine, University of Tehran, Qareeb St., Azadi Ave, Tehran, Iran

Full list of author information is available at the end of the article
}

transcriptase and integrated into the host cell genome by the integrase enzyme [8]. For this to happen, long terminal repeats in the viral genome play a vital role in the tissue attack and the pathogenicity of the virus [9].

The FeLV is one of the most important pathogens in cats with significant pathologies, which can significantly lower life expectancy in infected cats [10]. During the first few weeks after the initial infection, cats may have the following clinical signs: blood cytopenias (deficiency of any of the various cellular elements normally present in the blood), lethargy and enlarged lymph nodes. Clinical signs depend on viral subgroup and the stage of disease. Common general clinical signs include anemia (pale gums), hyporexia, decreased stamina, depression, diarrhea or constipation, excessive drinking and urination, infertility, jaundice, fever, lymphadenopathy, weight loss, poor coat condition, and neuropathies, with subsequent anisocoria, and hind limb paralysis [11]. 
Degenerative and neoplastic conditions of the hemopoietic system can be directly attributed to naturally occurring FeLV infection [7]. Hematological disorders, especially cytopenias, due to myelosuppression or myelodysplasia, are common findings in cats infected with FeLV [12, 13], resulting in anemia of myelodysplastic syndrome, aplastic anemia (pancytopenia), transient, persistent and cyclic neutropenias, panleukopenia-like syndrome, and platelet abnormalities [12, 14, 15].

The p27 core viral antigen is the target used for inclinic diagnostic testing for FeLV, such as rapid immunochromatography and enzyme-linked immunosorbent assays.

In some infection stages, FeLV is found in some tissues, such as cornea, spleen, lymph nodes, or epithelial tissues [7], but not in the bone marrow [8], which is a tissue where infection is usually considered a necessary stage for disease progression. FeLV infection is also associated with viremia, although p27 antigen negativity cannot necessarily rule out the infection [16]. Indeed, more sensitive molecular methods should be adopted when FeLV is suspected [16]. However, there is no comprehensive study on the quantification of FeLV RNA viral load in different tissues of cats with hematological cytopenias. In this study, whole blood, bone marrow and spleen specimens were obtained from 31 cats with hematopoietic cytopenias with suspicion of FeLV infections to detect the presence of the FeLV and to compare the number of viral RNA by an absolute reversetranscriptase quantitative polymerase chain reaction (RT-qPCR) technique in lymphohematogenic tissues.

\section{Results}

\section{Characteristics of the study population}

Demography of all cases, together with clinical and hematological findings is summarized in Table 1. Serum p27 antigen tests of animals included in this study revealed that 24 out of 31 cats with hematological cytopenias $(77.41 \%)$ were positive for the presence of FeLV antigen. Meanwhile, by RT-qPCR, viral RNA copy numbers were detected in all the cats (Table 2). Viral RNA could be traced back in all tissues examined, including the whole blood, bone marrow, and spleen. The median age of the FeLV positive feline population in this study was 3.1 year (range: from 1 to10 years). There was a male predominance (21 out of $31,68 \%$ ) in this case population. As much as $55 \%$ of these FeLV positive cats were sexually intact and $45 \%$ were neutered. The breeds of the feline population were domestic short-haired (DSH) and Persian. All cats included in this study were kept indoor, with 6 of them having free access to the outside. Most common abnormal clinical findings in these cats were oral inflammation (55\%), fever (55\%), and diarrhea (38.7\%). None of the patients had simultaneous FIV infection. Nine cats suffered from nonregenerative anemia alone (29.03\%), 4 from thrombocytopenia alone (12.90\%), 2 from nonregenerative neutropenia (6.45\%), 9 from bicytopenia of nonregenerative anemia and thrombocytopenia (12.90\%), 3 from bicytopenia of nonregenerative anemia and neutropenia (9.67\%), and 4 from pancytopenia (12.90\%). Cats of this study with nonregenerative anemia had PCV ranging from 8 to $27 \%$ (median, 17.1\%), with absolute reticulocyte counts ranging from 1000 to $49,000 / \mu \mathrm{L}$ (median, $11,700 / \mu \mathrm{L})$. Cats with nonregenerative neutropenia had neutrophil counts ranging from 910 to $1992 / \mu \mathrm{L}$ (median, 1337/ $\mu \mathrm{L}$ ). Platelet counts in cats with thrombocytopenia ranged from 9000 to $96,000 / \mu \mathrm{L}$ (median, $49,000 / \mu \mathrm{L})$. Serum biochemistry in cats of our study was normal except for total bilirubin. 20 out of 30 (81\%) cats of the study had hyperbilirubinemia ranging from 0.43 to $2.8 \mathrm{mg} / \mathrm{dl}$ (reference range: $0.1-0.4 \mathrm{mg} / \mathrm{dl}$ ) (median: $1.54 \mathrm{mg} / \mathrm{dl}$ ).

\section{FeLV detection in the whole blood, bone marrow and spleen of cats with hematological cytopenias}

In this study, we evaluated and compared the number of viral RNA in the whole blood, bone marrow and spleen of cats by an absolute RT-qPCR technique. Our results showed a significantly greater numbers of viral RNA in the spleen $(22,031 \pm 20,529)$ compared with the whole blood $(4641 \pm 5777)$ and bone marrow $(2664 \pm 2528)$ $\left(P_{\text {(spleen versus whole blood or bone marrow) }}<0.001\right)$ (Fig. 1 and Table 2). We found no correlation between cytopenias and the number of viral RNA in these hemolymphatic tissues.

We determined a cut-off value for viral RNA that resulted in serum p27 antigen positivity. For this purpose, we first ranked patients based on the number of viral RNA in whole blood and then categorized them into four groups (a quartile categorization) [17]. Our analyses revealed that the number of cases with serum p27 positivity in the first quartile was significantly lower than other quartiles $(P=0.009)$, whereas there was no significant differences between other quartiles. Therefore, in quartile 1, a final cut-off value of $94.5 \pm 33.4$ was determined as the number of viral RNA resulting in p27 antigen positivity in the serum.

\section{Discussion}

The existing literature regarding the quantitative detection of FeLV virus in various reticuloendothelial tissues is profoundly limited. Most of published works about the molecular detection of FeLV have focused on the presence of FeLV in the peripheral blood [1, 2, 4, 18-20]. In this study, we evaluated the presence of FeLV in the whole blood, bone marrow and spleen, and tried to comparatively quantitate the number of viral RNA by RT-qPCR in these 
Table 1 Demographics of 31 cats included in this study

\begin{tabular}{|c|c|c|c|c|c|c|c|}
\hline $\begin{array}{l}\text { Cat } \\
\text { No }\end{array}$ & $\begin{array}{l}\text { Age } \\
\text { (Year) }\end{array}$ & Gender & $\begin{array}{l}\text { Sexual } \\
\text { status }\end{array}$ & Breed & Clinical findings & Hematology findings & $\begin{array}{l}\text { Serum } \\
\text { FeLV p27 }\end{array}$ \\
\hline 1 & 2 & Male & Neutered & DSH & Oral inflammation, Cachexia, Icterus & Anemia & + \\
\hline 2 & 2 & Male & Intact & DSH & Oral inflammation, Cutaneous lesions, Icterus & Anemia & + \\
\hline 3 & 5 & Male & Intact & Persian & Oral inflammation, Diarrhea, Pale mucous membranes & $\begin{array}{l}\text { Anemia, Neutropenia, } \\
\text { Thrombocytopenia }\end{array}$ & + \\
\hline 4 & 1 & Male & Neutered & DSH & Cutaneous lesions, Icterus & Anemia, Neutropenia & + \\
\hline 5 & 6 & Male & Neutered & Persian & $\begin{array}{l}\text { Oral inflammation, Purulent nasal discharge, Pale mucous } \\
\text { membranes }\end{array}$ & Anemia & + \\
\hline 6 & 1 & Male & Neutered & Persian & Fever, Cachexia & Thrombocytopenia & + \\
\hline 7 & 4 & Male & Intact & Persian & $\begin{array}{l}\text { Oral inflammation, Cachexia, Diarrhea, Pale mucous } \\
\text { membranes }\end{array}$ & Anemia & - \\
\hline 8 & 10 & Female & Neutered & DSH & Oral inflammation, Fever, Icterus & Anemia, Neutropenia & - \\
\hline 9 & 2 & Male & Neutered & DSH & Cutaneous lesions, Diarrhea, Icterus & Anemia & + \\
\hline 10 & 1 & Female & Intact & DSH & Fever, Cachexia, Diarrhea & Anemia, Thrombocytopenia & + \\
\hline 11 & 3 & Female & Intact & DSH & Oral inflammation, Fever, Diarrhea & Thrombocytopenia & + \\
\hline 12 & 5 & Female & Neutered & Persian & Oral inflammation, Fever, Cutaneous lesions, Icterus & $\begin{array}{l}\text { Anemia, Neutropenia, } \\
\text { Thrombocytopenia }\end{array}$ & + \\
\hline 13 & 1 & Male & Intact & DSH & Fever, Purulent nasal discharge, Icterus & Anemia, Neutropenia & + \\
\hline 14 & 4 & Male & Intact & DSH & $\begin{array}{l}\text { Oral inflammation, Cutaneous lesions, pale mucous } \\
\text { membranes }\end{array}$ & Anemia, Thrombocytopenia & - \\
\hline 15 & 2 & Male & Neutered & DSH & Fever, Icterus & Anemia, Thrombocytopenia & - \\
\hline 16 & 1 & Female & Intact & DSH & Cachexia, Diarrhea & Thrombocytopenia & + \\
\hline 17 & 2 & Male & Intact & DSH & Oral inflammation, Fever, Diarrhea, Icterus & Anemia, Thrombocytopenia & + \\
\hline 18 & 6 & Male & Neutered & Persian & Fever, Cutaneous lesions, Diarrhea & Thrombocytopenia & - \\
\hline 19 & 4 & Male & Neutered & Persian & Purulent nasal discharge, Icterus & Neutropenia & + \\
\hline 20 & 2.5 & Male & Neutered & Persian & Fever, Purulent nasal discharge, Icterus & Anemia, Thrombocytopenia & + \\
\hline 21 & 1 & Male & Intact & DSH & Oral inflammation, Icterus & Anemia & - \\
\hline 22 & 4 & Female & Intact & DSH & Oral inflammation, Fever, Cachexia, Diarrhea & Anemia & + \\
\hline 23 & 3 & Male & Intact & DSH & Oral inflammation, Fever, Diarrhea, Icterus & Anemia, Thrombocytopenia & + \\
\hline 24 & 3 & Male & Neutered & Persian & Oral inflammation, Icterus & Anemia, Thrombocytopenia & + \\
\hline 25 & 1 & Male & Intact & DSH & $\begin{array}{l}\text { Fever, Cutaneous lesions, Diarrhea, Pale mucous } \\
\text { membranes }\end{array}$ & $\begin{array}{l}\text { Anemia, Neutropenia, } \\
\text { Thrombocytopenia }\end{array}$ & + \\
\hline 26 & 2 & Female & Intact & DSH & $\begin{array}{l}\text { Oral inflammation, Dermatological lesions, Pale mucous } \\
\text { membranes }\end{array}$ & Anemia, Thrombocytopenia & + \\
\hline 27 & 6 & Female & Neutered & Persian & Oral inflammation, Fever, Diarrhea & Anemia & + \\
\hline 28 & 3 & Female & Neutered & Persian & Fever, Purulent nasal discharge, Icterus & Neutropenia & + \\
\hline 29 & 1 & Male & Intact & DSH & Fever, Pale mucous membranes & Anemia & - \\
\hline 30 & 3 & Male & Intact & DSH & Fever, Cutaneous lesions, Pale mucous membranes & Anemia, Thrombocytopenia & + \\
\hline 31 & 5 & Female & Intact & Persian & $\begin{array}{l}\text { Oral inflammation, Cachexia, Cutaneous lesions, Diarrhea, } \\
\text { Pale mucous membranes }\end{array}$ & $\begin{array}{l}\text { Anemia, Neutropenia, } \\
\text { Thrombocytopenia }\end{array}$ & + \\
\hline
\end{tabular}

lymphohematogenic tissues of cats with hematological cytopenias. Based on circulating proviral DNA and p27 antigenemia, FeLV infected cats were categorized into four classes, designated as abortive, regressive, latent, and progressive [21]. FeLV viremia and viral shedding are considered as evidence of progressive infection, so that molecular detection of provirus, which was carried out by previous studies, might not necessarily lead to recognition of different outcomes of FeLV infection [8]. In the current study, we focused on molecular detection of viral RNA in important hemolymphatic tissues, including bone marrow, infection of which is usually considered a necessary stage for disease progression $[8,22]$. The molecular procedure used in this study could successfully detect the virus in the examined tissues of all cats with hematological cytopenias, which is indicative of a progressive infection [23]. Our 
Table 2 Number of FeLV RNA (per 20 ng extracted RNA) in the blood, bone marrow, and spleen of cats with hematological cytopenias

\begin{tabular}{|c|c|c|c|}
\hline Cat No. ${ }^{1}$ & Blood & Bone marrow & Spleen \\
\hline 1 & 10,285 & 1996 & 19,422 \\
\hline 2 & 16,710 & 7329 & 28,846 \\
\hline 3 & 9864 & 6633 & 51,459 \\
\hline 4 & 6308 & 788 & 161 \\
\hline 5 & 3069 & 2242 & 53 \\
\hline 6 & 13,282 & 847 & 9459 \\
\hline 7 & 884 & 5197 & 7544 \\
\hline 8 & 450 & 210 & 25,581 \\
\hline 9 & 2856 & 4516 & 18,869 \\
\hline 10 & 1235 & 2580 & 29,669 \\
\hline 11 & 1446 & 1612 & 6594 \\
\hline 12 & 1998 & 6910 & 11,014 \\
\hline 13 & 1340 & 5597 & 28,534 \\
\hline 14 & 287 & 165 & 11,179 \\
\hline 15 & 218 & 113 & 22,477 \\
\hline 16 & 238 & 1521 & 25,991 \\
\hline 17 & 449 & 2249 & 1845 \\
\hline 18 & 31 & 8295 & 18,023 \\
\hline 19 & 414 & 1880 & 9897 \\
\hline 20 & 259 & 654 & 10,355 \\
\hline 21 & 85 & 1036 & 20,654 \\
\hline 22 & 430 & 398 & 8204 \\
\hline 23 & 4000 & 1840 & 7928 \\
\hline 24 & 10,443 & 534 & 87,661 \\
\hline 25 & 15,835 & 2827 & 40,088 \\
\hline 26 & 7103 & 907 & 76,304 \\
\hline 27 & 16,584 & 646 & 20,421 \\
\hline 28 & 15,354 & 7732 & 7062 \\
\hline 29 & 83 & 69 & 42,229 \\
\hline 30 & 2163 & 2603 & 3078 \\
\hline 31 & 178 & 2661 & 32,368 \\
\hline
\end{tabular}

findings showed that the number of viral RNA in the spleen was remarkably higher than other tissues $(P<0.001)$. We could detect large numbers of FeLV RNA in just $20 \mathrm{ng}$ of total extracted RNA from the spleen, suggesting that even a less invasive fine needle aspiration might have given as effective a reading as a Tru-cut style biopsy for viral detection. It has been shown that the infection first occurs in the oropharynx, where the virus infects lymphocytes, and then the infected cells [24] carry the virus to other target tissues, such as bone marrow, thymus, spleen and lymph nodes [25].
Many authors showed that RNA loads represent ongoing viral replication somewhere in the cat's body even in sequestered places [8]. Other publications investigated that detection of RNA is generally less frequently accomplished than that of proviral DNA [8].

Due to its availability and quick turnaround time, ELISA is the most common testing method for the detection of FeLV. Previous studies have also shown that only a proportion of cats with FeLV-associated diseases are positive for circulating FeLV antigen $[2,16,26]$, which may be due to very low levels of infective virus, transient viremia, or latent or defective forms of FeLV. Indeed, PCR for detection of viral DNA or RNA has been proven to be an ideal procedure for the detection of viral DNA or RNA to diagnose cats with FeLV infection [27].

In this study, we demonstrated the presence of FeLV infection in all the 31 cats with a kind of hematologic cytopenia, including anemia, leukopenia, and/or thrombocytopenia, which is consistent with the association of refractory hematologic cytopenias and myelodysplasia with FeLV infection in cats $[2,28-30]$. Indeed, there is some evidence that cats with unexplained peripheral blood cytopenias that have FeLV antigen-negative tests are often suspected to be suffering from latent FeLV infection [13]. In this study, 7 out of 31 cats $(22.5 \%)$ with a kind of cytopenia were serum p27 antigen negative, indicating further that negativity for FeLV antigen cannot rule out the infection unless the lack of FeLV viral RNA is shown by molecular methods [31, 32].

\section{Conclusions}

Given serum p27 antigen detection has generally lower sensitivity than molecular techniques in FeLV-infected cats, PCR-based molecular methods of viral detection is recommended in suspected cats. According to our findings, spleen should be considered a site where FeLV is most abundantly found in cats with refractory hematologic cytopenias.

\section{Methods \\ Sample collection}

A total of 31 cats with clinical signs typical of FeLVassociated immunosuppression, including oral inflammation (gingivitis, stomatitis), fever with unknown origin, chronic purulent nasal discharge without therapeutic improvement, cachexia, cutaneous lesions, chronic diarrhea, and pale mucous membranes were enrolled in this study [33] (Table 1). Cats with at least two of these clinical signs were included in this study as described previously [31]. The cats were subjected to a clinical examination with a Veterinarian at the time of sample collection in addition to filling in a detailed questionnaire. All procedures of this study were approved by the Animal Care Committee of the University of Tehran. Inclusion criteria were as follows: at least one hematologic cytopenia including (1) anemia (PCV $\leq 30 \%$ and absolute count of 


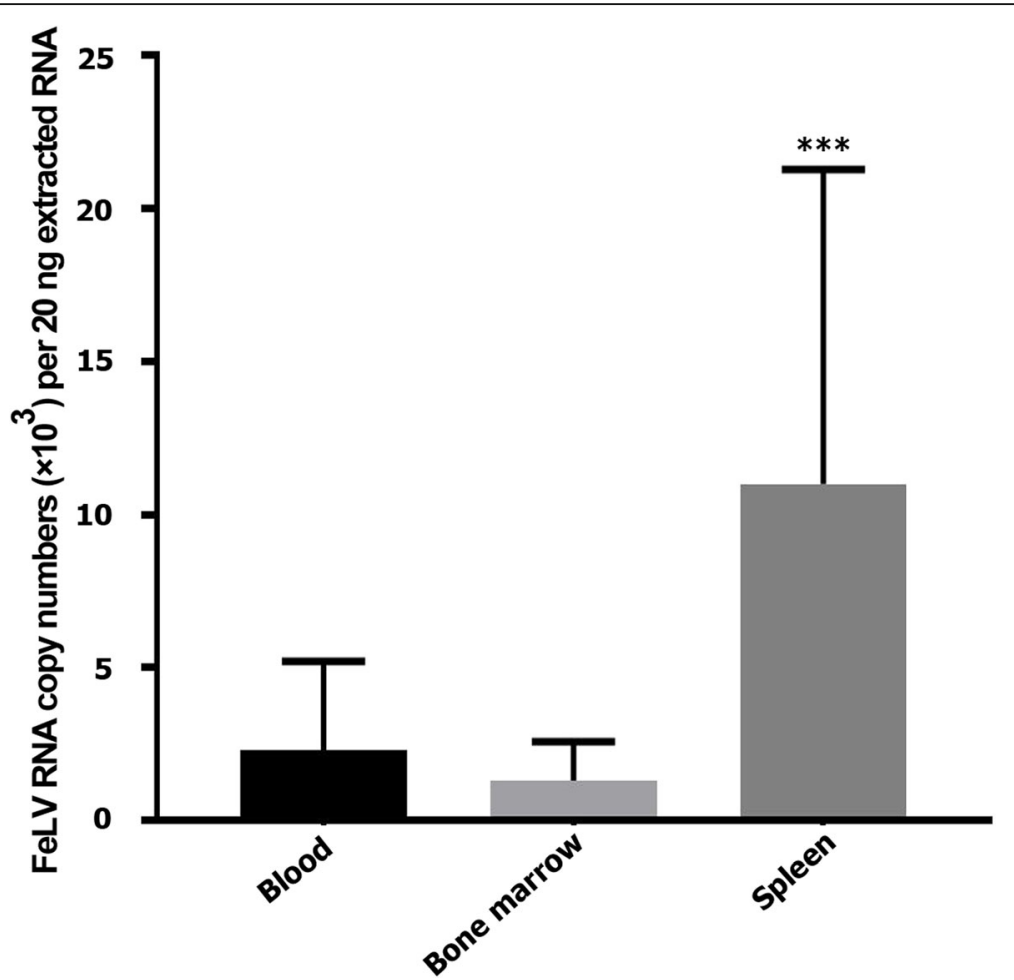

Fig. 1 Quantification of FeLV RNA in the blood, bone marrow, and spleen of cats with hematological cytopenias. Data are expressed as mean \pm SD. ${ }^{* * *} P<0.001$, spleen versus blood and bone marrow (One-way ANOVA with Tukey post-hoc)

reticulocytes $<50,000$ per microliter), (2) neutropenia (neutrophil counts of less than 2500 per microliter and absolute neutrophil band counts of less than 400 cell per microliter), (3) thrombocytopenia (absolute count of platelets $<100,000$ per microliter and no bleeding). Exclusion criteria included FIV positive cats, iron deficiency anemia and thrombocytopenia due to bleeding.

For this study, peripheral blood $(3 \mathrm{~mL} / \mathrm{sample})$ with or without EDTA anticoagulant, bone marrow and spleen specimens were obtained from each cat. The complete blood counts (CBCs) and biochemical analyses, including total protein, albumin, alanine aminotransferase, aspartate aminotransferase, alkaline phosphatase, total bilirubin, urea, creatinine, glucose, calcium, phosphorus, total cholesterol, and triglyceride were performed using an automated cell counter (Nihon Kohden Celltac alpha, MEK6450, Tokyo, Japan) and automated chemistry analyzer (Selectra ProM, ELITech Group, Puteaux, France) respectively. A commercially available rapid immunochromatography test (Feline Leukemia Virus Antigen/Feline Immunodeficiency Virus Antibody Test Kit, IDEXX Laboratories, Maine 04092, USA) was performed to detect FeLV p27 antigen in sera of animals.

Bone marrow was obtained from the humerus with a 14-G bone marrow needle under general anesthesia (xylazine $2 \%(0.5 \mathrm{mg} / \mathrm{kg}, \mathrm{I} . \mathrm{V}$, Alfesan, Holland) and ketamine $10 \%$ (10 mg/kg,I.V Alfesan, Holland) after surgical preparation and disinfection. Bone marrow samples were placed in EDTA tubes.

For biopsy of the spleen, cats were anesthetized as described above. For this purpose, animals were placed in right lateral recumbency, and the area behind the last rib was prepared surgically. We then introduced the biopsy needle (Semi-Automatic biopsy needle, GTA Medical product, Italy) via ultrasound guidance. None of the cats included in this study was subjected to euthanasia after sample collection.

\section{RNA extraction}

Peripheral blood, bone marrow and spleen specimens obtained from each cat were subjected to RNA extraction using a high pure viral RNA purification kit (Cat No: PR891620, AryoGen Biopharma Complex. Karaj, Iran). For this purpose, $100 \mu \mathrm{l}$ whole blood or bone marrow and $25 \mathrm{mg}$ fresh crushed spleen tissues were added to $1.5 \mathrm{ml}$ micro centrifuge tube containing $400 \mu \mathrm{l}$ lysis solutions and mixed thoroughly by vortexing for $20 \mathrm{~s}$.

After extraction, RNA concentration was measured at $260 \mathrm{~nm}$ with a Nanodrop ND-1000 spectrophotometer (Nanodrop Technologies, Wilmington, DE, USA). Comparable RNA $(3.9 \pm 0.4 \mathrm{ng} / \mu \mathrm{l})$ concentrations were determined in the whole blood, bone marrow and spleen samples. After measurement of RNA concentration in 
each sample, a total of $20 \mathrm{ng}$ RNA was used for RTqPCR as described below.

\section{RT-qPCR}

FeLV-specific RNA was detected by RT-qPCR (ABI 7700, Applied Biosystems, Foster City, CA) using a commercially available kit (genesig ${ }^{\circ}$ Advanced Kit. England), which contained FeLV specific primer/probe mix, FeLV positive control template, internal extraction control primer/probe mix, internal extraction control RNA, endogenous control primer/probe mix, FeLV/internal extraction control/endogenous control RT primer mix, RNAse/DNAse free water and template preparation buffer. A FeLV positive control template was provided to generate an absolute standard curve of FeLV copy number (Additional 1: Figure. S1). Also, an RNAse/ DNAse free water was used as negative control to validate any positive findings. FeLV specific primer and probe mix provided in the kit was detected using the FAM channel. During PCR amplification, forward and reverse primers were hybridized to the FeLV cDNA. A fluorogenic probe was included in the same reaction mixture which consists of a DNA probe labeled with a $5{ }^{`}$-dye and a $3^{`}$-quencher. During amplification, the probe is cleaved and the reporter dye and quencher are separated. Amplification was carried out as follows: $55^{\circ} \mathrm{C}$ for $10 \mathrm{~min}$ ( 1 cycle) and $95^{\circ} \mathrm{C}$ for $2 \mathrm{~min}$ ( 1 cycle), followed by denaturation at $95^{\circ} \mathrm{C}$ for $10 \mathrm{~s}$ and annealing at $60^{\circ} \mathrm{C}$ for $60 \mathrm{~s}$ ( 50 cycles). The standard curve was diluted from $2 \times 105$ per $\mu \mathrm{l}$ to $2 \mu \mathrm{l}$ to obtain the quantification range.

\section{Statistical analysis}

Data analysis was performed using SPSS.22 statistical package (Chicago, USA). Frequency of the data was described as mean $\pm \mathrm{SD}$ values for continuous variables and as proportions for categorical data. Data normality was tested using Kolmogorov-smirnov analysis. One-way ANOVA and Chi-square tests were used to compare groups with continuous variables and categorical data, respectively. The correlation analysis was performed using Spearman's test. To determine a cut-off value based on the number of viral RNA in blood resulting in serum positivity, patients were first ranked based on the number of viral RNA in blood and then categorized into the four groups (quartile) as described previously for cut-off determination [17]. Following that, the number of cases with the disease between groups was compared using Chi-square test. This analysis revealed that number of cases with FeLV in the quartile 1 was significantly lower than other quartiles $(P=0.009)$. Thus, the mean of blood viral RNA copy numbers in this group was considered as a final cut-off value.

\section{Supplementary information}

Supplementary information accompanies this paper at https://doi.org/10. 1186/s12917-019-2208-y.

Additional file 1. Figure. S1.Reverse-transcriptase quantitative polymerase chain reaction (RT-qPCR) of FeLV RNA. (A) $1 \times 10^{0}$ to $1 \times 10^{-6}$ serial dilutions of FeLV RNA were prepared and detected by real time PCR, with $2 \times 10^{5}$ to $2 \times 10^{0}$ viral RNA copy numbers in the prepared dilutions. (B) Standard curve of the prepared dilutions.

\section{Abbreviations}

FeLV: Feline leukemia virus; RT-qPCR: Reverse-transcriptase quantitative polymerase chain reaction

\section{Acknowledgements}

Not applicable.

\section{Authors' contributions}

MAP, SJ, and SMN conceptualized the study, performed experiments, analyzed data and wrote the manuscript. MZA contributed to data analysis and drafting the manuscript. All authors read, edited and approved the final manuscript.

\section{Funding}

This study was supported by a research grant from the University of Tehran. The funding institute was not involved in the study design, data collection and analysis, interpretation of results, or writing the manuscript for publication.

\section{Availability of data and materials}

The data used and/or analysed during the current study are available from the corresponding author on reasonable request.

\section{Ethics approval and consent to participate}

All phases of this study were approved by the Animal Care Committee of the University of Tehran. Written informed consent was obtained from the cat owners for their cats to be used in this study.

\section{Consent for publication}

Not applicable.

\section{Competing interests}

The authors declared no potential conflicts of interest with respect to the research, authorship, and/ or publication of this article.

\section{Author details}

${ }^{1}$ Department of Internal Medicine, Faculty of Veterinary Medicine, University of Tehran, Tehran, Iran. ${ }^{2}$ Department of Clinical Pathology, Faculty of Veterinary Medicine, University of Tehran, Qareeb St., Azadi Ave, Tehran, Iran. ${ }^{3}$ Department of Clinical Sciences, Faculty of Veterinary Medicine, Shahid Bahonar University of Kerman, Kerman, Iran.

Received: 2 June 2019 Accepted: 4 December 2019

Published online: 19 December 2019

References

1. Arjona A, Barquero N, Doménech A, Tejerizo G, Collado VM, Toural C, Martín D, Gomez-Lucia E. Evaluation of a novel nested PCR for the routine diagnosis of feline leukemia virus (FeLV) and feline immunodeficiency virus (FIV). J Feline Med Surg. 2007;9(1):14-22.

2. Arjona A, Escolar E, Soto I, Barquero N, Martin D, Gomez-Lucia E. Seroepidemiological survey of infection by feline leukemia virus and immunodeficiency virus in Madrid and correlation with some clinical aspects. J Clin Microbiol. 2000;38(9):3448-9.

3. McLuckie A, Barrs V, Wilson B, Westman M, Beatty J. Felis catus gammaherpesvirus 1 DNAemia in whole blood from therapeutically immunosuppressed or retrovirus-infected cats. Vet Sci. 2017;4(1):16.

4. Sumi R, Miyake A, Endo T, Ohsato Y, Ngo MH, Nishigaki K. Polymerase chain reaction-based detection of myc transduction in feline leukemia virusinfected cats. Arch Virol. 2018;163(4):1073-7. 
5. Chiu ES, Hoover EA, VandeWoude S. A retrospective examination of feline leukemia subgroup characterization: viral interference assays to deep sequencing. Viruses. 2018;10(1):29.

6. Gomes-Keller M, Gönczi E, Tandon R, Riondato F, Hofmann-Lehmann R, Meli $M L$, Lutz $H$. Detection of feline leukemia virus RNA in saliva from naturally infected cats and correlation of PCR results with those of current diagnostic methods. J Clin Microbiol. 2006;44(3):916-22.

7. Herring IP, Troy GC, Toth TE, Champagne ES, Pickett JP, Haines DM. Feline leukemia virus detection in corneal tissues of cats by polymerase chain reaction and immunohistochemistry. Vet Ophthalmol. 2001;4(2):119-26.

8. Major A, Cattori V, Boenzli E, Riond B, Ossent P, Meli ML, Hofmann-Lehmann $\mathrm{R}$, Lutz $\mathrm{H}$. Exposure of cats to low doses of FeLV: seroconversion as the sole parameter of infection. Vet Res. 2010;41(2):1-10.

9. Abujamra AL, Spanjaard RA, Akinsheye I, Zhao X, Faller DV, Ghosh SK. Leukemia virus long terminal repeat activates NFKB pathway by a TLR3dependent mechanism. Virology. 2006;345(2):390-403.

10. Liem BP, Dhand NK, Pepper AE, Barrs VR, Beatty JA. Clinical findings and survival in cats naturally infected with feline immunodeficiency virus. J Vet Intern Med. 2013;27(4):798-805.

11. Ellis J, Bell R, Barnes D, Miller R. Prevalence and disease associations in feline thrombocytopenia: a retrospective study of 194 cases. J Small Anim Pract. 2018;59(9):531-8.

12. Reinacher M. Diseases associated with spontaneous feline leukemia virus (FeLV) infection in cats. Vet Immunol Immunopathol. 1989;21(1):85-95.

13. Stützer B, Müller F, Majzoub M, Lutz H, Greene C, Hermanns W, Hartmann K. Role of latent feline leukemia virus infection in nonregenerative cytopenias of cats. J Vet Intern Med. 2010;24(1):192-7.

14. Lutz H, Castelli I, Ehrensperger F, Pospischil A, Rosskopf M, Siegl G, Grob M Martinod S. Panleukopenia-like syndrome of FeLV caused by co-infection with FeLV and feline panleukopenia virus. Vet Immunol Immunopathol. 1995;46(1-2):21-33.

15. Shelton G, Linenberger M. Hematologic abnormalities associated with retroviral infections in the cat. Semin Vet Med Surg (Small Anim). 1995;10(4): 220-33.

16. Sharifi H, Nassiri SM, Esmaelli $H$, Khoshnegah J. Eosinophilic leukaemia in a cat. J Feline Med Surg. 2007:9(6):514-7.

17. Rosenwald A, Wright G, Chan WC, Connors JM, Campo E, Fisher RI, Gascoyne RD, Muller-Hermelink HK, Smeland EB, Giltnane JM. The use of molecular profiling to predict survival after chemotherapy for diffuse largeB-cell lymphoma. N Engl J Med. 2002;346(25):1937-47.

18. Boenzli E, Hadorn M, Hartnack S, Huder J, Hofmann-Lehmann R, Lutz H. Detection of antibodies to the feline leukemia virus (FeLV) transmembrane protein p15E: an alternative approach for serological FeLV detection based on antibodies to p15E. J Clin Microbiol. 2014;52(6):2046-52.

19. Bande F, Arshad SS, Hassan L, Zakaria Z, Sapian NA, Rahman NA, Alazawy A. Prevalence and risk factors of feline leukaemia virus and feline immunodeficiency virus in peninsular Malaysia. BMC Vet Res. 2012;8(1):33.

20. Bande F, Arshad SS, Hassan L, Zakaria Z. Molecular detection, phylogenetic analysis, and identification of transcription motifs in feline leukemia virus from naturally infected cats in Malaysia. Vet Med Int. 2014;760961.

21. Torres AN, Mathiason CK, Hoover EA. Re-examination of feline leukemia virus: host relationships using real-time PCR. Virology. 2005;332(1):272-83.

22. Cattori V, Pepin AC, Tandon R, Riond B, Meli ML, Willi B, Lutz H, HofmannLehmann R. Real-time PCR investigation of feline leukemia virus proviral and viral RNA loads in leukocyte subsets. Vet Immunol Immunopathol. 2008; 123(1-2):124-8.

23. Helfer-Hungerbuehler AK, Widmer S, Kessler $Y$, Riond B, Boretti FS, Grest P, Lutz H, Hofmann-Lehmann R. Long-term follow up of feline leukemia virus infection and characterization of viral RNA loads using molecular methods in tissues of cats with different infection outcomes. Virus Res. 2015;197:137-50.

24. Lutz H, Addie D, Belák S, Boucraut-Baralon C, Egberink H, Frymus T, Gruffydd-Jones T, Hartmann K, Hosie MJ, Lloret A. Feline leukaemia. ABCD guidelines on prevention and management. J Feline Med Surg. 2009;11(7): 565-74

25. de Melo FAC, dos Santos AC, Nogueira K, ARdCB Vianna, Agreste FR, de Castro MB, EMM de Lima. Expression of spleen structural components of FeLV-positive and FeLV-negative cats (Felis catus). Asian J Anim Vet Adv. 2015;10(6):281-7.
26. Cotter S, Hardy JW, Essex M. Association of feline leukemia virus with lymphosarcoma and other disorders in the cat. J Am Vet Med Assoc. 1975; 166(5):449-54

27. Jackson ML, Haines DM, Taylor SM, Misra V. Feline leukemia virus detection by ELISA and PCR in peripheral blood from 68 cats with high, moderate, or low suspicion of having FeLV-related disease. J Vet Diagn Investig. 1996;8(1): 25-30.

28. Hartmann K. Clinical aspects of feline retroviruses: a review. Viruses. 2012; 4(11):2684-710

29. McManus PM. Classification of myeloid neoplasms: a comparative review. Vet Clin Pathol. 2005:34(3):189-212.

30. Mackey L. Feline leukaemia virus and its clinical effects in cats. Vet Rec. 1975:96(1):5-11.

31. Bardshiri B, Mashhadirafie S, Seifiabadshapouri R. A case-controlled study of FeLV infected cats in Tehran, Iran, confirmed by immunochromatography and RTPCR and correlation with clinical and hematological findings. Slov Vet Res. 2011;48(2):57-64.

32. Hardy W Jr. Feline leukemia virus non-neoplastic disease. J Am Anim Hosp Assoc. 1981;17:941-9.

33. Little S, Bienzle D, Carioto L, Chisholm H, O'Brien E, Scherk M. Feline leukemia virus and feline immunodeficiency virus in Canada: recommendations for testing and management. Can Vet J. 2011;52(8): $849-55$

\section{Publisher's Note}

Springer Nature remains neutral with regard to jurisdictional claims in published maps and institutional affiliations.
Ready to submit your research? Choose BMC and benefit from:

- fast, convenient online submission

- thorough peer review by experienced researchers in your field

- rapid publication on acceptance

- support for research data, including large and complex data types

- gold Open Access which fosters wider collaboration and increased citations

- maximum visibility for your research: over $100 \mathrm{M}$ website views per year

At BMC, research is always in progress.

Learn more biomedcentral.com/submissions 